\title{
Synthesis of cadmium complexes of 4 '-chloro-terpyridine: From discrete dimer to 1D chain polymer, crystal structure and antibacterial activity
}

\author{
LOTFALI SAGHATFOROUSH ${ }^{\mathrm{a}, *}$, LAURA VALENCIA MATARRANZ ${ }^{\mathrm{b}}$, \\ FIROOZEH CHALABIAN $^{\mathrm{c}}$, SHAHRIARE GHAMMAMY ${ }^{\mathrm{d}}$ and FATEMEH KATOUZIAN ${ }^{\mathrm{e}}$ \\ ${ }^{a}$ Department of Chemistry, Payame Noor University, 19395-4697, Tehran, I.R. of Iran \\ ${ }^{b}$ Departamento de Quimica Inorganica, Facultad de Quimica, Universidade de Vigo, \\ 36310 Vigo Pontevedra, Spain \\ ${ }^{\mathrm{c}}$ Department of Biology, Tehran North Campus, Islamic Azad University, Tehran, Iran \\ ${ }^{\mathrm{d}}$ Department of Chemistry, Imam Khomeini International University, Qazvin, Iran \\ ${ }^{\text {e }}$ Department of Microbiology, Tehran North Campus, Islamic Azad University, Tehran, Iran \\ e-mail: saghatforoush@gmail.com
}

MS received 16 August 2011; revised 8 December 2011; accepted 30 December 2011

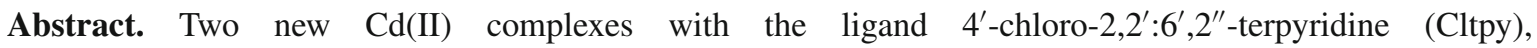
$\left[\mathrm{Cd}(\mathrm{Cltpy})\left(\mathrm{N}_{3}\right)\left(\mathrm{CH}_{3} \mathrm{COO}\right)\right], \mathbf{1}$, and $\left[\mathrm{Cd}(\mathrm{Cltpy})(\mathrm{NCS})\left(\mathrm{CH}_{3} \mathrm{COO}\right)\right]_{\mathrm{n}}, \mathbf{2}$, have been synthesized and characterized by CHN elemental analyses, ${ }^{1} \mathrm{H}$ NMR-, ${ }^{13} \mathrm{C}$ NMR-, IR spectroscopy and structurally analysed by X-ray singlecrystal diffraction. The single crystal X-ray analyses show that the coordination number in these complexes is seven with three terpyridine (Cltpy) N-donor atoms, two acetate oxygens and two anionic bridged ligands. The crystal structure of $\mathbf{2}$ comprises a one-dimensional polymeric network bridged by $\mathrm{NCS}^{-}$anions. The antibacterial activities of Cltpy and its Cd(II) complexes are tested against different bacteria. Both complexes have shown good activity against all the tested bacteria. Against Klebsiella pneumonia and Staphylococcus aureus, antibacterial activity of complexes is higher than Cltpy ligand. The higher activity of complexes may be explained on the basis of chelation theory.
\end{abstract}

Keywords. $\quad$ Cd(II) Complexes; 4'-chloro-2,2' $: 6^{\prime}, 2^{\prime \prime}$-terpyridine (Cltpy); synthesis; crystal structure; antibacterial properties.

\section{Introduction}

Terpyridine is a tridentate ligand that binds metals at three meridional sites giving two adjacent 5-membered $\mathrm{MN}_{2} \mathrm{C}_{2}$ chelate rings. Because they are pi-acceptors, terpy stabilize metals in lower oxidation states. In the past few years, considerable attention has been drawn to the family of metal complexes having $2,2^{\prime}: 6^{\prime}, 2^{\prime \prime}$ terpyridine (tpy) or substituted tpy components due to their structural advantage in drug design, material chemistry and photofunctional supramolecular assemblies. ${ }^{1-7}$ Tpy derivatives offered interesting prospects for metal-activated drug delivery system, where the activity could be switched by metal-ion coordination through the study of the interactions between bioreceptors and ligand with sugar substituents. ${ }^{8}$

Supramolecular aggregation via molecular selfassembly has been an important issue in the field of structural chemistry recently. ${ }^{7,8}$ Besides the electrostatic interaction, non-covalent forces also play an

*For correspondence important role in determination of the structural stacking and the properties of molecules. ${ }^{9}$ In addition, the interactions between the aromatic rings are found to be critical for the molecular packing in crystallization. ${ }^{10}$ Furthermore, the hydrogen bond, a powerful organizing force in designing solids due to its directionality, selectivity and reversible formation at room temperature, may significantly influence the molecular packing in the crystal engineering. It is reasonable to predict that the cadmium compounds on Cltpy and appropriate linkers, such as halide and pseudo-halide $\mathrm{X}(\mathrm{Cl}, \mathrm{Br}, \mathrm{I}, \mathrm{SCN}$ or $\mathrm{CN})$, can be developed from monomers to polymers. ${ }^{11}$

The Cltpy ligand contains one widely used $2,2^{\prime}: 6^{\prime}, 2^{\prime \prime}-$ terpyridine (terpy) coordinative site and another $\mathrm{Cl}^{-}$ site at the $4^{\prime}$-position, these two sites are able to bind with different metal ions, thus leading to the coordination polymers with various frameworks. ${ }^{12}$

In clinical applications and biochemistry, functionalized terpyridines have found a wide range of potential uses, ranging from colorimetric metal determination to DNA binding agents. ${ }^{13}$ Because of the binding to nucleic acids, metal terpyridine complexes have the 
ability or potential to serve as anticancer, antibacterial, and antiparasitic drugs. ${ }^{14,15}$ Although summarized in this section, the exact mechanisms are not known in some cases, and may involve protein binding or membrane binding.

To extend our studies to coordination and supramolecular chemistry of this tridentate ligand, we present in this paper the preparation and structural characterizations of two 1:1 metal/ligand complexes, $\left[\mathrm{Cd}(\mathrm{Cltpy})\left(\mathrm{N}_{3}\right)\left(\mathrm{CH}_{3} \mathrm{COO}\right)\right], \mathbf{1}$, and $[\mathrm{Cd}(\mathrm{Cltpy})(\mathrm{NCS})$ $\left.\left(\mathrm{CH}_{3} \mathrm{COO}\right)\right]_{\mathrm{n}}, 2$. The structural and biological properties of these new complexes have been studied.

\section{Experimental}

\subsection{Materials and measurements}

All chemicals were reagent grade and used without further purification. Elemental analyses $(\mathrm{CHN})$ were performed using a Carlo ERBA model EA 1108 analyzer. FT-IR spectra were collected on a Shimadzu- IR Prestige 21 spectrophotometer in the range of 4000$400 \mathrm{~cm}^{-1}$ using $\mathrm{KBr}$ pellets. ${ }^{1} \mathrm{H}$ and ${ }^{13} \mathrm{C}$ NMR spectra were recorded with a Bruker spectrometer at $250 \mathrm{MHz}$ in $\mathrm{D}_{6}$-DMSO. Thermal analyses were carried out on a Perkin-Elmer instrument (Seiko Instruments).

\subsection{Antibacterial activity test}

In vitro activity test was carried out using the growth inhibitory zone (well method). ${ }^{16-19}$ The potency of components was determined against the three Grampositive bacteria: Streptococcus pyogenes (RITCC 1940), Staphylococcus aureus (RITCC 1885), and Bacillus anthracis (RITCC 1036), and also against the three Gram-negative bacteria: Klebsiella pneumonia (RITCC 1249), Escherichia Coli (RITCC 1330), and Pseudomonas aeruginosa (RITCC 1547). Microorganisms (obtained from enrichment culture of the microorganisms in $1 \mathrm{~mL}$ Muller-Hinton broth incubated at $37^{\circ} \mathrm{C}$ for $12 \mathrm{~h}$ ) were cultured on Muller-Hinton agar medium. The inhibitory activity was compared with that of standard antibiotics, such as gentamicin $(10 \mu \mathrm{g})$. After drilling wells on the medium using a $6 \mathrm{~mm}$ cork borer, $100 \mu \mathrm{L}$ of solution from different compounds were poured into each well. The plates were incubated at $37^{\circ} \mathrm{C}$ overnight. The diameter of the inhibition zone was measured as precisely as possible. Each test was carried out in triplicate and the average was calculated for inhibition zone diameters. A blank containing only methanol showed no inhibition in a preliminary test. The macrodilution broth susceptibility assay was used for the evaluation of minimal inhibitory concentration (MIC). ${ }^{17}$

\subsection{Preparation of $\left[\mathrm{Cd}(\mathrm{Cltpy})\left(\mathrm{N}_{3}\right)\left(\mathrm{CH}_{3} \mathrm{COO}\right)\right] \mathrm{I}$}

$4^{\prime}$-chloro-2,2':6',2"-terpyridine $(0.268 \mathrm{~g}, 1 \mathrm{mmol})$ was placed in one arm of a branched tube and cadmium (II) acetate $(0.264 \mathrm{~g}, 1 \mathrm{mmol})$ and sodium azide $(0.13 \mathrm{~g}$, $2 \mathrm{mmol}$ ) in the other. Methanol was carefully added to fill both arms. After two days, the crystals that had deposited in the cooler arm were filtered off, washed with diethylether, and air dried. Yield: $82 \%$. Analysis found: $\mathrm{C}: 42.39, \mathrm{H}: 2.68, \mathrm{~N}: 17.40 \%$. Calculated for $\mathrm{C}_{17} \mathrm{H}_{13} \mathrm{CdClN}_{6} \mathrm{O}_{2}: \mathrm{C}: 42.44, \mathrm{H}: 2.72, \mathrm{~N}, 17.47 \%$. IR $\left(\mathrm{cm}^{-1}\right)$ selected bands: 670(w), 798(s), 815(w), 1005(m), 1161(w), 1280(w), 1338(m), 1411(s), 1477(m), 1558(bs), 1611(w), 2054(s), 2080(w), 2925(w), 3055(m). ${ }^{1} \mathbf{H}$ NMR (DMSO, $\delta$ ): 7.770 (t, 2H), 8.211 (t, 2H), 8.339 (s, 2H), $8.776(\mathrm{~m}, 4 \mathrm{H}), 1.913(\mathrm{~s}, 3 \mathrm{H}) \mathrm{ppm} .{ }^{13} \mathbf{C} \mathbf{~ N M R}$ (DMSO, $\delta$ ): 122.94, 123.24, 125.95, 140.19, 140.29, $150.21,150.30,178.09,22.41 \mathrm{ppm}$.

\subsection{Preparation of $\left[\mathrm{Cd}(\mathrm{Cltpy})(\mathrm{NCS})\left(\mathrm{CH}_{3} \mathrm{COO}\right)\right]_{\mathrm{n}} 2$}

Complex 2 was synthesized in the same way as complex 1 using potassium thiocianate in place of sodium azide. Yield: 74\%. Analysis: found: C: 43.41, $\mathrm{H}: 2.67, \mathrm{~N}$ : 11.21\%. Calculated for $\mathrm{C}_{18} \mathrm{H}_{13} \mathrm{CdClN}_{4} \mathrm{O}_{2} \mathrm{~S}: \mathrm{C}: 43.48$, H: 2.64, N, 11.27\%. IR $\left(\mathrm{cm}^{-1}\right)$ selected bands: $678(\mathrm{w})$, 794(m), 821(m), 1005(m), 1160(w), 1430(m), 1480(m), 1550(s), 1590(s), 2035(s), 2060(s), 2823(w), 3038(w), 3100(w). ${ }^{1} \mathbf{H}$ NMR (DMSO, $\delta$ ): $7.828(\mathrm{t}, 2 \mathrm{H}), 8.261$ (t, 2H), 8.883 (m, 4H), 9.063 (s, 2H), $2.010(\mathrm{~s}, 3 \mathrm{H}) \mathrm{ppm}$. ${ }^{13}$ C NMR (DMSO, $\delta$ ): 122.94, 123.64, 127.32, 127.76, $140.65,150.39,155.59,176.12,22.54 \mathrm{ppm}$.

\section{$2.5 X$-ray crystallography}

2.5a Structure determination: Data collection for $\mathrm{X}$-ray crystal structure determinations was performed on a STOE IPDS I/II diffractometer using graphitemonochromated $\mathrm{Mo}-\mathrm{K}_{\alpha}$ radiation $(\lambda=0.71073 \AA)$. The data were corrected for Lorentz and polarization effects. A numerical absorption correction based on crystal-shape optimization was applied for all data. The programs used in this work are Stoe's X-Area, including X-RED and X-Shape for data reduction and absorption correction, and the WinGX suite of programs, including SIR-92 and SHELXL-97 for structure solution and refinement. ${ }^{20}$ The hydrogen atoms were placed in idealized positions and constrained to ride on their parent atom. The last cycles of refinement included atomic 
Table 1. Crystallographic data of $\mathbf{1}$ and 2.

\begin{tabular}{|c|c|c|}
\hline Identification code & (1) & (2) \\
\hline Empirical formula & $\mathrm{C} 18 \mathrm{H} 13 \mathrm{Cd} \mathrm{Cl}$ N4 O2 S & C17 H13 Cd Cl N6 O2 \\
\hline Formula weight & 497.23 & 481.18 \\
\hline Temperature & 293(2) K & 293(2) K \\
\hline Wavelength & $0.71073 \mathrm{~A}$ & $0.71073 \mathrm{~A}$ \\
\hline Crystal system & Orthorrombic & Triclinic \\
\hline Space group & Pca2(1) & $\mathrm{P}-1$ \\
\hline \multirow[t]{6}{*}{ Unit cell dimensions } & $a=17.1477(15) \AA$ & $a=9.481(3) \AA$ \\
\hline & $\mathrm{b}=15.9787(13) \AA$ & $\mathrm{b}=10.666(4) \AA$ \\
\hline & $\mathrm{c}=13.3678(11) \AA$ & $\mathrm{c}=10.702(4) \AA$ \\
\hline & $\alpha=90^{\circ}$ & $\alpha=63.336(6)^{\circ}$ \\
\hline & $\beta=90^{\circ}$ & $\beta=67.974(6)^{\circ}$ \\
\hline & $\gamma=90^{\circ}$ & $\gamma=79.505(6)^{\circ}$ \\
\hline Volume & $3662.8(5) \AA^{3}$ & $896.4(5) \AA^{3}$ \\
\hline $\mathrm{Z}$ & 8 & 2 \\
\hline Density (calculated) & $1.803 \mathrm{~g} \mathrm{~cm}^{-3}$ & $1.783 \mathrm{~g} \mathrm{~cm}^{-3}$ \\
\hline Absorption coefficient & $1.474 \mathrm{~mm}^{-1}$ & $1.393 \mathrm{~mm}^{-1}$ \\
\hline$F(000)$ & 1968 & 476 \\
\hline Crystal size & $0.47 \times 0.36 \times 0.34 \mathrm{~mm}^{3}$ & $0.37 \times 0.11 \times 0.10 \mathrm{~mm}^{3}$ \\
\hline Theta range for data collection & 1.27 to $25.01^{\circ}$ & 2.14 to $25.03^{\circ}$ \\
\hline \multirow[t]{3}{*}{ Index ranges } & $-19 \leq \mathrm{h} \leq 20$ & $-11 \leq \mathrm{h} \leq 10$ \\
\hline & $-18 \leq \mathrm{k} \leq 19$ & $-12 \leq \mathrm{k} \leq 12$ \\
\hline & $-9 \leq 1 \leq 15$ & $-12 \leq 1 \leq 9$ \\
\hline Reflections collected & 18566 & $4 \overline{6} 18$ \\
\hline Independent reflections & 4812 & 3097 \\
\hline Absorption correction & Empirical & Empirical \\
\hline Max. and min. transmission & 0.6341 and 0.5442 & 0.8732 and 0.6267 \\
\hline \multirow{2}{*}{ Refinement method } & Full-matrix & Full-matrix \\
\hline & least-squares on $F^{2}$ & least-squares on $F^{2}$ \\
\hline Data / restraints / parameters & 4812 / 1 / 489 & 3097 / 0 / 245 \\
\hline Goodness-of-fit on $\mathrm{F}^{2}$ & 1.183 & 0.998 \\
\hline \multirow[t]{2}{*}{ Final $R$ indices $[I>2 \sigma(I)]$} & $\mathrm{R}_{1}=0.0214$ & $\mathrm{R}_{1}=0.0506$ \\
\hline & $\mathrm{wR}_{2}=0.0525$ & $\mathrm{wR}_{2}=0.1290$ \\
\hline \multirow[t]{2}{*}{$R$ Indices (all data) } & $\mathrm{R}_{1}=0.0252$ & $\mathrm{R}_{1}=0.0673$ \\
\hline & $\mathrm{wR}_{2}=0.0547$ & $w R_{2}=0.1403$ \\
\hline Largest diff. Peak, hole & 0.315 and $-0.261 \mathrm{e} . \AA^{-3}$ & 1.484 and $-1.520 \mathrm{e} . \AA^{-3}$ \\
\hline
\end{tabular}

positions for all atoms, anisotropic thermal parameters for all non-hydrogen atoms and isotropic thermal parameters for all hydrogen atoms. Materials for publication were prepared using Mercury and ORTEP-3. ${ }^{21,22}$ The summary of the crystal data, experimental details and refinement results of $\mathbf{1 , 2}$ are listed in table 1.

\section{Results and discussion}

\subsection{Spectroscopic studies}

The reaction of cadmium acetate with $4^{\prime}$-chloro$2,2^{\prime}: 6^{\prime}, 2^{\prime \prime}$-terpyridine (Cltpy) yielded crystalline materials formulated as $\left[\mathrm{Cd}(\mathrm{Cltpy})\left(\mathrm{N}_{3}\right)\left(\mathrm{CH}_{3} \mathrm{COO}\right)\right] \mathbf{1}$ and $\left[\mathrm{Cd}(\mathrm{Cltpy})(\mathrm{NCS})\left(\mathrm{CH}_{3} \mathrm{COO}\right)\right] 2$. The IR spectra display characteristic absorption bands for the tpyCl ligands and for the azide, acetate and thiocyanate anions. The relatively weak absorption bands at around 30383100 and $2823-2951 \mathrm{~cm}^{-1}$ are due to the $\mathrm{C}-\mathrm{H}$ modes involving the aromatic ring and aliphatic hydrogen atoms, respectively. The absorption bands with variable intensity in the frequency range $1400-1620 \mathrm{~cm}^{-1}$ correspond to aromatic ring vibrations of the tpyCl ligand. In complex $1, v_{\text {as }}\left(\mathrm{N}_{3}\right)$ appears as a very strong splitting band at 2045 and $2087 \mathrm{~cm}^{-1}$ is assigned to the existence of end-on bridging azide ligand. ${ }^{23,24}$ The strong $v_{\text {as }}(\mathrm{SCN})$ absorption peaks at 2092 and $2045 \mathrm{~cm}^{-1}$ for complex 2 show the presence of $\mathrm{S}$ - and $\mathrm{N}$-coordinated thiocyanate ligand. ${ }^{23-25}$

The ${ }^{1} \mathrm{H}-\mathrm{NMR}$ spectra of DMSO solutions of complexes $\mathbf{1}$ and $\mathbf{2}$ at room temperature show two triplets, a singlet and a multiplet for the aromatic protons of Cltpy ligand. One singlet in 1.913 and $2.01 \mathrm{ppm}$ assigned to the presence of $-\mathrm{CH}_{3}$ group of the acetate ion in 
complexes 1 and $\mathbf{2}$, respectively. The singlet signal of $-\mathrm{CH}_{3}$ group of the methanol in complex $\mathbf{1}$ is observed in $3.405 \mathrm{ppm}$. The ${ }^{13} \mathrm{C}-\mathrm{NMR}$ spectra of DMSO solutions of these compounds show eight distinct peaks assigned to the aromatic carbon atoms of the pyridine rings of the Cltpy ligands and the signal for acetate groups appeared in 22.54 and $22.41 \mathrm{ppm}$.

\subsection{Structural analysis}

The solid state structure of compounds $\mathbf{1}$ and $\mathbf{2}$ were determined by single crystal X-ray diffraction. Crystal and structure refinement data of the two compounds are given in table 1. X-ray crystal analysis reveals that compound $\mathbf{1}$ crystallizes in Triclinic with space group P-1. The crystal structure of compound 1 consists a of dimeric units of $\left[\mathrm{Cd}(\mathrm{Cltpy})\left(\mu-\mathrm{N}_{3}\right)\left(\mathrm{CH}_{3} \mathrm{COO}\right)\right]_{2}$ (figure 1). Each cadmium atom chelated by three Cltpy nitrogen atoms, two bridge nitrogen atoms and acetate two oxygen atoms. The coordination number in this complex is seven with two of the azide nitrogen atoms forming two bridges between two cadmium ions to produce dimeric units in the solid state. The resulting coordination number of seven is augmented with $\mathrm{CdN}_{5} \mathrm{O}_{2}$ molecule core.

By comparison of bond lengths and bond angels around each cadmium atoms, it is found that each cadmium have monocapped octahedral geometry that abbreviated as 2:4:1. The unit cell and packing schema of this complex is shown in figure 2. Molecules occupied only corners of cells and have not formed a closed packed system; it may be because of short contacts between molecules that caused similar orientation of molecules in unit cell. The six $\mathrm{Cd}-\mathrm{N}$ bond distances fall in the range of 2.383(5)-2.404(5) $\AA$ which are typical for Cd-Ntpy coordination compounds. ${ }^{26}$ Each
Cltpy coordinates $\mathrm{Cd}$ atom to form two five-member $\mathrm{Cd}-\mathrm{N}-\mathrm{C}-\mathrm{C}-\mathrm{N}$ metalcycles. The central pyridine ring of 1 (N2C6-C10) forms a dihedral angle of $4.28^{\circ}$ with the plane (N1C1-C5) and an angle of $5.31^{\circ}$ with the other plane (N3C11-C15), showing that the three connected planes are slightly far from coplanarity. $\mathrm{Cd} 1 \cdots \mathrm{Cd} 1$ distance in each dimer is $3.790 \AA$ and $\mathrm{Cl} 1 \cdots \mathrm{Cl} 1$ distance between two discrete dimers is $3.563 \AA$. $\mathrm{C}-\mathrm{H} \cdots \mathrm{O}$ and $\mathrm{C}-\mathrm{H} \cdots \mathrm{N}$ hydrogen bonding and $\mathrm{Cl} 1 \cdots \mathrm{Cl} 1$ interactions are responsible for keeping two discrete dimer complexes near. These types of bonding along with $\pi-\pi$ stacking supramolecular interactions are believed to be responsible for the arrangement of molecules in the $\mathbf{1}$ crystal packing. The centroidto-centroid separations between neighbouring pyridine rings are $3.679 \AA$, exhibiting typical $\pi-\pi$ stacking interactions in an offset fashion.

Single crystal X-ray analysis reveals that compound $\left[\mathrm{Cd}(\mathrm{Cltpy})(\mathrm{NCS})\left(\mathrm{CH}_{3} \mathrm{COO}\right)\right]_{\mathbf{n}}$ (2) crystallizes in a orthorhombic system with space group of $P$ ca2(1). Determination of the structure of the compound $\mathbf{2}$ by $\mathrm{X}$-ray crystallography showed (figure 3 ) the asymmetric unit of 2 comprises two independent mononuclear cadmium complexes with seven coordinate, $\mathrm{Cd}_{1} \mathrm{~N}_{4} \mathrm{O}_{2} \mathrm{~S}$ (2A) and $\mathrm{Cd} 2 \mathrm{~N}_{4} \mathrm{O}_{2} \mathrm{~S}$ (2B) (figure 3). The $\mathrm{Cd}-\mathrm{N}$ distances in both independent complexes, falling in the range of 2.355(3)-2.401(3) $\AA$, are all within the normal range, except the bond to the central pyridyl ring that is longer than those to terminal rings in $\mathbf{2 A}$. In all synthesized complexes the $\mathrm{Cd}-\mathrm{N}_{\text {central py }}$ distance is not shorter than $\mathrm{Cd}-\mathrm{N}_{\text {terminal py }}$ and this is against the previous reports about the metal complexes of tpy and $4^{\prime}-$ tpy derivatives. ${ }^{26}$

The central pyridine ring of $\mathbf{2 A}(\mathrm{N} 2 \mathrm{C} 6-\mathrm{C} 10)$ forms a dihedral angle of $4.13^{\circ}$ with the plane (N1C1-C5) and an angle of $6.64^{\circ}$ with the other plane (N3C11-C15), while the central pyridine ring of $\mathbf{2 B}$ (N6C24-C28)
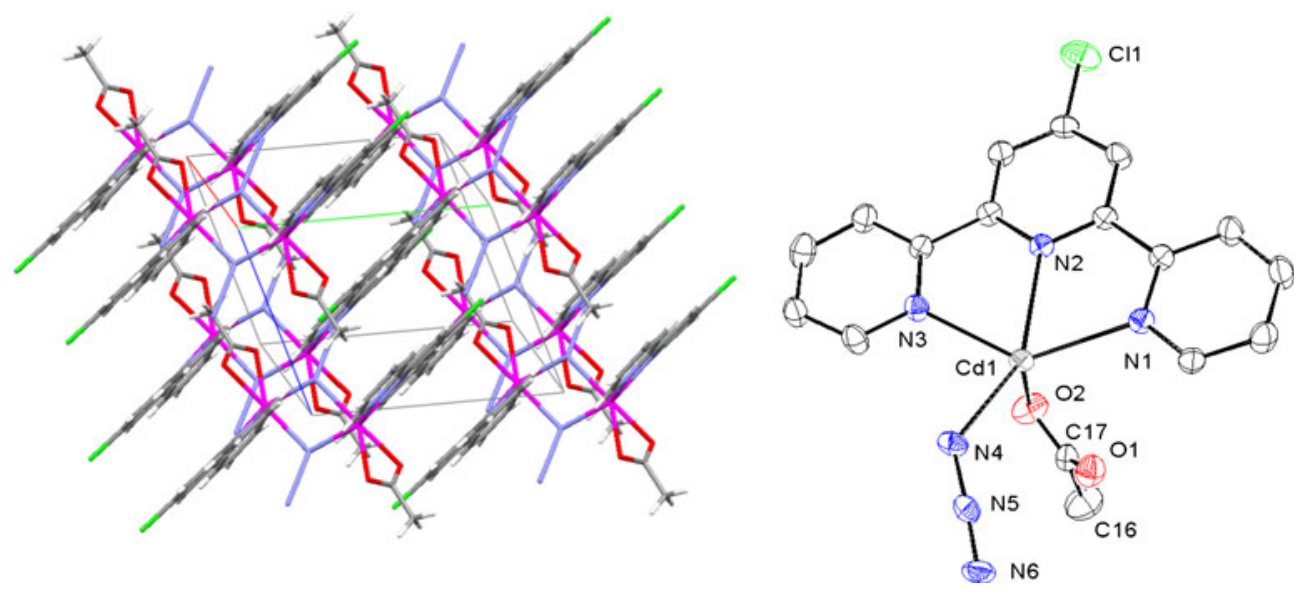

Figure 1. X-Ray crystal structure of $\left[\mathrm{Cd}(\mathrm{Cltpy})\left(\mathrm{N}_{3}\right)\left(\mathrm{CH}_{3} \mathrm{COO}\right)\right],(\mathbf{1})$. 


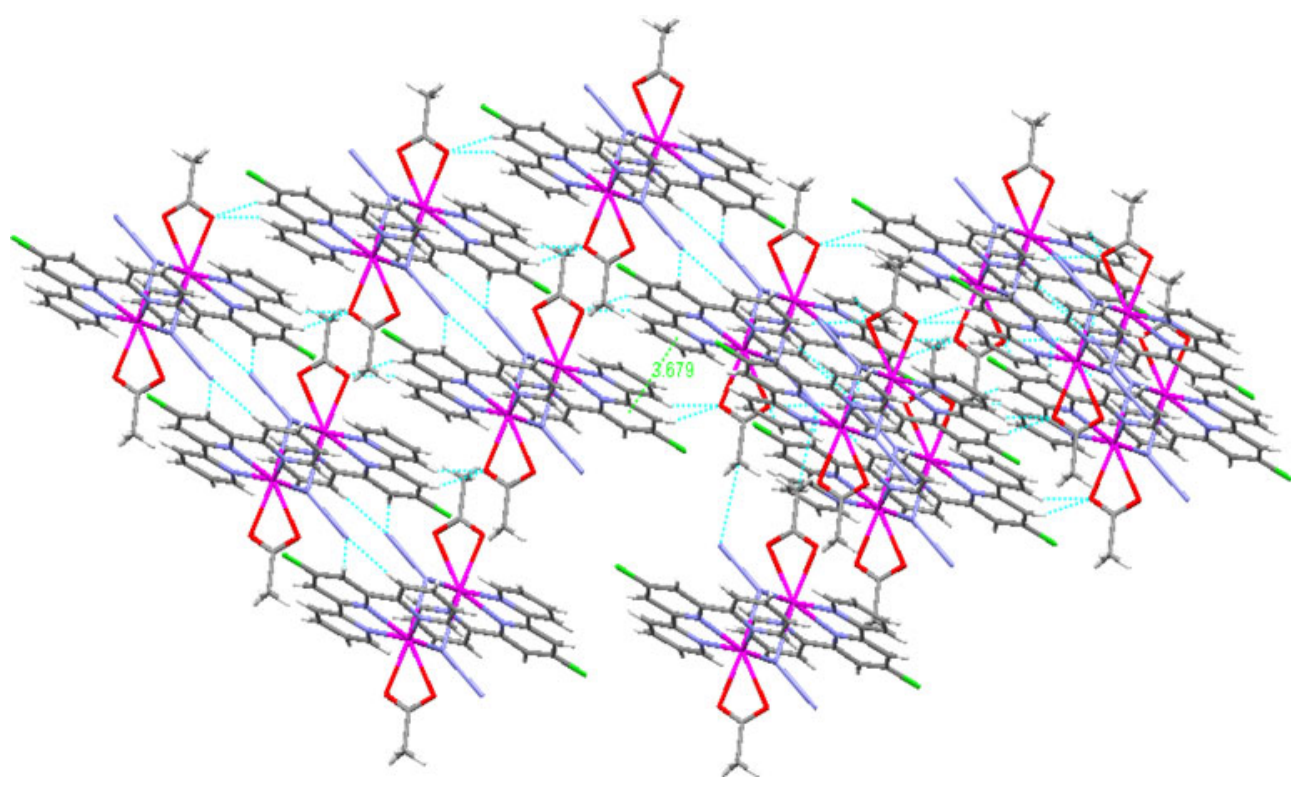

Figure 2. The unit cell of $\left[\mathrm{Cd}(\mathrm{Cltpy})\left(\mathrm{N}_{3}\right)\left(\mathrm{CH}_{3} \mathrm{COO}\right)\right]$, (1), as shown (layer packing).

forms a dihedral angle of $9.54^{\circ}$ with the plane (N5C19$\mathrm{C} 23$ ) and an angle of $8.27^{\circ}$ with the other plane (N7C29-C33), showing that the three connected planes are far from coplanarity in $\mathbf{2 B}$ with respect to $\mathbf{2 A}$.

Versatile hydrogen bonding including weak $\mathrm{C}-\mathrm{H} \cdot \mathrm{Cl}$ hydrogen bonds and $\pi-\pi$ stacking supramolecular interactions are believed to be responsible for the arrangement of molecules in the $\mathbf{2}$ crystal packing. The centroid-to-centroid separations between neighbouring pyridine rings are 3.581 and $3.907 \AA$, exhibiting typical $\pi-\pi$ stacking interactions in an offset fashion. O4. .H14 hydrogen bonding is responsible for keeping two independent polymer chains near. The crystal structure comprises a one-dimensional polymeric network bridged by $\mathrm{NCS}^{-}$anions.

The unit cell and packing schema of $\mathbf{2}$, is shown in figure 4. Molecules occupied half of tetrahedral holes and used zinc blend system that is not a closed packed system. Selected bond lengths and angels of two compounds are given in table 2 .

\subsection{Antibacterial activity}

The antibacterial activities of Cltpy and its Cd(II) complexes are shown in table 3. Although antibacterial activity of complex $\mathbf{1}$ against Pseudomonas aeruginosa and Escherichia coli is better than complex 2, both complexes have good activity against all tested bacteria. ${ }^{17}$ It should be noticed that the antibacterial activity of all tested compounds are higher than standard antibiotic (gentamicin) against Pseudomonas aeruginosa, Streptococcus pyogenes and Klebsiella pneumonia. Among the tested Cd(II) complexes, it is obvious that

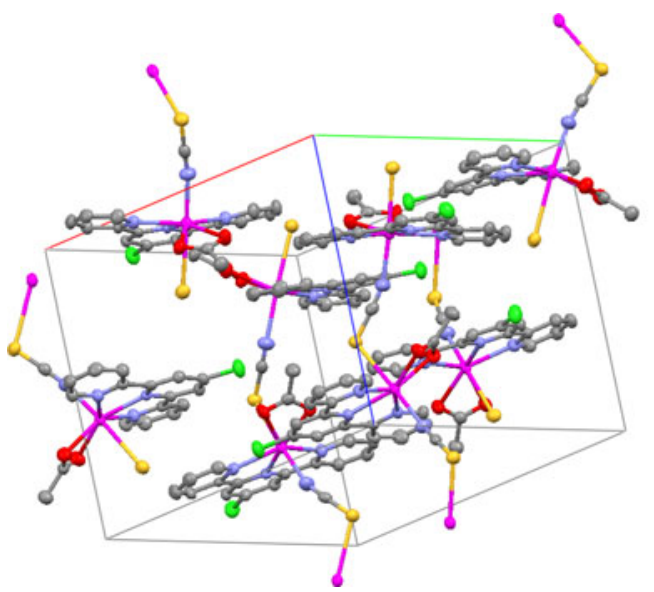

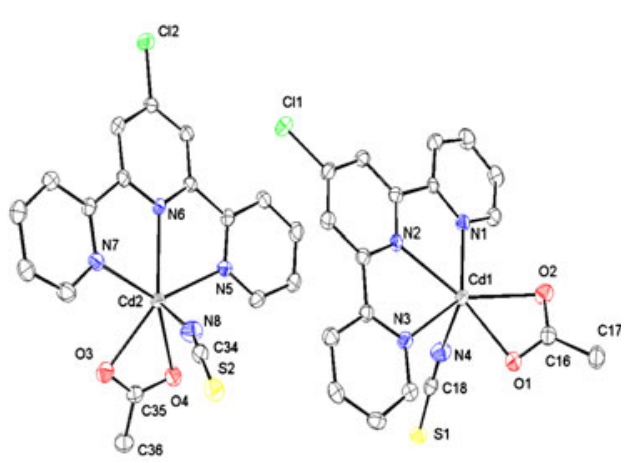

Figure 3. X-Ray crystal structure of $\left[\mathrm{Cd}(\mathrm{Cltpy})(\mathrm{NCS})\left(\mathrm{CH}_{3} \mathrm{COO}\right)\right]_{\mathrm{n}},(\mathbf{2})$. 


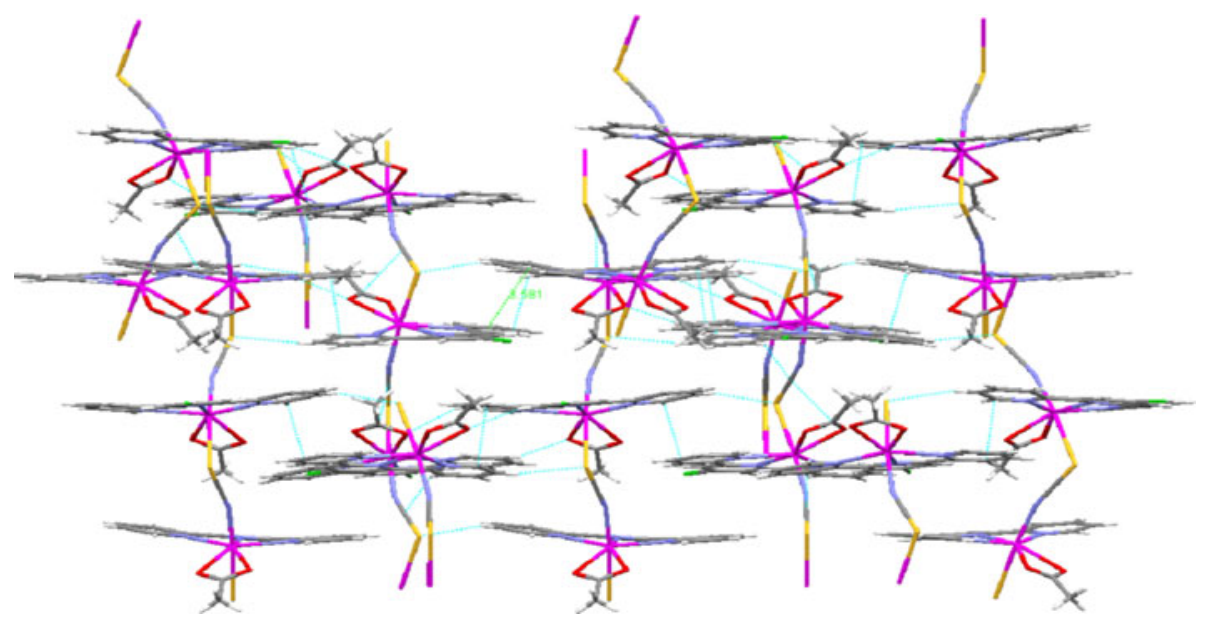

Figure 4. The unit cell of $\left[\mathrm{Cd}(\mathrm{Cltpy})(\mathrm{NCS})\left(\mathrm{CH}_{3} \mathrm{COO}\right)\right]_{\mathrm{n}},(\mathbf{2})$, as shown (layer packing).

antibacterial activity of complex $\mathbf{1}$ against Pseudomonas aeruginosa and Esherichia coli is stronger than the other complex. Against Klebsiella pneumonia and Staphylococcus aureus, antibacterial activity of complexes is higher than Cltpy ligand. The higher activity of complexes may be explained on the basis of chelation theory. ${ }^{17}$ Also, the better antibacterial activity of complexes $\mathbf{1}$ and $\mathbf{2}$ are probably due to existence $\mathrm{SCN}^{-}$ and $\mathrm{N}_{3}^{-}$anions in their structures. ${ }^{18,19}$ The antibacterial effects of cadmium acetate as a control are shown in table 4. These results show that cadmium acetate has higher antibacterial effects when it is used individually when compared to ligand itself and complexes. However, the mixture of cadmium acetate and ligand as a complex still show strong antibacterial effects on bacteria compared to ligand itself. So it can be concluded

Table 2. Selected bond lengths/Å and angles $/{ }^{\circ}$ for $\mathbf{1 , 2}$.

(2)

(1)

\begin{tabular}{|c|c|c|c|c|c|}
\hline $\mathrm{Cd} 1-\mathrm{N} 1$ & $2.356(3)$ & $\mathrm{O} 1-\mathrm{Cd} 1-\mathrm{O} 2$ & $55.0(1)$ & $\mathrm{Cd} 1-\mathrm{N} 1$ & $2.383(7)$ \\
\hline $\mathrm{Cd} 1-\mathrm{N} 3$ & $2.386(3)$ & N5-Cd2-N6 & $67.7(1)$ & $\mathrm{Cd} 1-\mathrm{N} 2$ & $2.398(4)$ \\
\hline $\mathrm{Cd} 1-\mathrm{N} 2$ & $2.401(3)$ & N5-Cd2-N7 & 134.6(1) & $\mathrm{Cd} 1-\mathrm{N} 3$ & $2.403(7)$ \\
\hline $\mathrm{Cd} 1-\mathrm{N} 4$ & $2.347(5)$ & N5-Cd2-N8 & $95.4(1)$ & $\mathrm{Cd} 1-\mathrm{N} 4$ & $2.454(6)$ \\
\hline $\mathrm{Cd} 1-\mathrm{O} 1$ & $2.313(3)$ & $\mathrm{N} 5-\mathrm{Cd} 2-\mathrm{O} 3$ & $138.7(1)$ & $\mathrm{Cd} 1-\mathrm{N} 4^{\mathrm{i}}$ & $2.302(5)$ \\
\hline $\mathrm{Cd} 1-\mathrm{O} 2$ & $2.444(3)$ & $\mathrm{N} 5-\mathrm{Cd} 2-\mathrm{O} 4$ & $86.3(1)$ & $\mathrm{Cd} 1-\mathrm{O} 1$ & $2.568(5)$ \\
\hline $\mathrm{Cd} 1-\mathrm{S} 1$ & $2.945(1)$ & $\mathrm{N} 6-\mathrm{Cd} 2-\mathrm{N} 8$ & 111.1(1) & $\mathrm{Cd} 1-\mathrm{O} 2$ & $2.309(7)$ \\
\hline $\mathrm{Cd} 2-\mathrm{N} 5$ & $2.385(3)$ & $\mathrm{N} 6-\mathrm{Cd} 2-\mathrm{O} 3$ & $138.9(1)$ & N1-Cd1-N2 & $67.8(2)$ \\
\hline $\mathrm{Cd} 2-\mathrm{N} 6$ & $2.374(3)$ & N6-Cd2-O4 & $145.7(2)$ & N1-Cd1-N3 & $135.3(2)$ \\
\hline $\mathrm{Cd} 2-\mathrm{N} 7$ & $2.355(3)$ & $\mathrm{N} 7-\mathrm{Cd} 2-\mathrm{O} 3$ & $84.2(1)$ & N1-Cd1-N4 & $129.2(2)$ \\
\hline $\mathrm{Cd} 2-\mathrm{N} 8$ & $2.300(5)$ & $\mathrm{N} 7-\mathrm{Cd} 2-\mathrm{O} 4$ & $138.5(1)$ & $\mathrm{N} 1-\mathrm{Cd} 1-\mathrm{N} 4^{\mathrm{i}}$ & $86.9(2)$ \\
\hline $\mathrm{Cd} 2-\mathrm{O} 3$ & $2.436(3)$ & $\mathrm{N} 8-\mathrm{Cd} 2-\mathrm{O} 3$ & $98.4(1)$ & N1-Cd1-O1 & $79.7(2)$ \\
\hline $\mathrm{Cd} 2-\mathrm{O} 4$ & $2.320(4)$ & $\mathrm{N} 8-\mathrm{Cd} 2-\mathrm{O} 4$ & $92.7(1)$ & N1-Cd1-O2 & $102.0(2)$ \\
\hline $\mathrm{Cd} 2-\mathrm{S}$ & $3.099(1)$ & $\mathrm{O} 3-\mathrm{Cd} 2-\mathrm{O} 4$ & $54.4(1)$ & N2-Cd1-N4 & $151.6(2)$ \\
\hline $\mathrm{N} 1-\mathrm{Cd} 1-\mathrm{N} 2$ & $68.0(1)$ & & & $\mathrm{N} 2-\mathrm{Cd} 1-\mathrm{N} 4^{\mathrm{i}}$ & $85.6(2)$ \\
\hline $\mathrm{N} 1-\mathrm{Cd} 1-\mathrm{N} 3$ & $134.8(1)$ & & & N2-Cd1-O1 & $125.0(2)$ \\
\hline $\mathrm{N} 1-\mathrm{Cd} 1-\mathrm{N} 4$ & $94.8(1)$ & & & N2-Cd1-O2 & $92.0(2)$ \\
\hline $\mathrm{N} 1-\mathrm{Cd} 1-\mathrm{O} 1$ & $138.5(1)$ & & & N3-Cd1-N4 & $90.0(2)$ \\
\hline $\mathrm{N} 1-\mathrm{Cd} 1-\mathrm{O} 2$ & 83.6(1) & & & $\mathrm{N} 3-\mathrm{Cd} 1-\mathrm{N} 4^{\mathrm{i}}$ & $84.3(2)$ \\
\hline $\mathrm{N} 2-\mathrm{Cd} 1-\mathrm{N} 4$ & 104.2(1) & & & N3-Cd1-O1 & $132.6(2)$ \\
\hline $\mathrm{N} 2-\mathrm{Cd} 1-\mathrm{O} 1$ & 149.1(1) & & & N3-Cd1-O2 & $85.0(2)$ \\
\hline $\mathrm{N} 2-\mathrm{Cd} 1-\mathrm{O} 2$ & $142.4(1)$ & & & N4-Cd1-O1 & $82.9(2)$ \\
\hline $\mathrm{N} 3-\mathrm{Cd} 1-\mathrm{O} 1$ & $86.4(1)$ & & & N4-Cd1-O2 & $103.9(2)$ \\
\hline $\mathrm{N} 3-\mathrm{Cd} 1-\mathrm{O} 2$ & $139.5(1)$ & & & $\mathrm{N} 4-\mathrm{Cd} 1-\mathrm{N} 4^{\mathrm{i}}$ & $74.4(2)$ \\
\hline $\mathrm{N} 4-\mathrm{Cd} 1-\mathrm{O} 1$ & $90.8(1)$ & & & $\mathrm{O} 1-\mathrm{Cd} 1-\mathrm{O} 2$ & $52.2(2)$ \\
\hline \multirow[t]{2}{*}{$\mathrm{N} 4-\mathrm{Cd} 1-\mathrm{O} 2$} & $102.3(1)$ & & & $\mathrm{O} 1-\mathrm{Cd} 1-\mathrm{N} 4^{\mathrm{i}}$ & $136.8(2)$ \\
\hline & & & & $\mathrm{O} 2-\mathrm{Cd} 1-\mathrm{N} 4^{\mathrm{i}}$ & $169.1(2)$ \\
\hline
\end{tabular}


Table 3. Intermolecular interactions in crystals of $\mathbf{1 , 2}$.

\begin{tabular}{|c|c|c|c|}
\hline A $\cdots H-B$ & $\mathrm{H} \cdots \mathrm{A} / \AA$ & $\mathrm{B} \cdots \mathrm{A} / \AA$ & $\mathrm{B}-\mathrm{H} \cdots \mathrm{A} /{ }^{\circ}$ \\
\hline (1) & & & \\
\hline $\mathrm{O} 2 \cdots \mathrm{H} 25-\mathrm{C} 25(-\mathrm{x}, \mathrm{y},-\mathrm{z}+1 / 2)$ & 2.590 & $3.484(2)$ & 161.44 \\
\hline $\mathrm{O} 1 \cdots \mathrm{H} 20-\mathrm{C} 20(\mathrm{x}+1 / 2,-\mathrm{y}+1 / 2, \mathrm{z}+1 / 2)$ & 2.551 & $3.314(2)$ & 139.60 \\
\hline $\mathrm{O} 4 \cdots \mathrm{H} 14-\mathrm{C} 14(\mathrm{x}+1 / 2, \mathrm{y}+1 / 2, \mathrm{z})$ & 2.418 & $3.275(1)$ & 153.61 \\
\hline $\mathrm{Cl} 2 \cdots \mathrm{H} 33(-\mathrm{x}+1 / 2, \mathrm{y}+1 / 2,-\mathrm{z}+1 / 2)$ & 2.997 & $3.922(2)$ & 173.02 \\
\hline $\mathrm{Cl} 1 \cdots \mathrm{H} 1(-\mathrm{x}+1 / 2, \mathrm{y}+1 / 2,-\mathrm{z}+1 / 2)$ & 2.959 & $3.858(1)$ & 162.64 \\
\hline $\mathrm{C} 11 \cdots \mathrm{C} 23(-\mathrm{x}+1 / 2, \mathrm{y}+1 / 2,-\mathrm{z}+1 / 2)$ & & $3.655(1)$ & \\
\hline $\mathrm{Cl} 2 \cdots \mathrm{C} 2(-\mathrm{x},-\mathrm{y},-\mathrm{z})$ & & 3.540 & \\
\hline $\mathrm{C} 34 \cdots \mathrm{C} 35(-\mathrm{x}, \mathrm{y},-\mathrm{z}+1 / 2)$ & & $3.331(2)$ & \\
\hline $\mathrm{C} 18 \cdots \mathrm{C} 16(-\mathrm{x}, \mathrm{y},-\mathrm{z}+1 / 2)$ & & $3.276(2)$ & \\
\hline$\pi \cdots \pi$ (slipped face-to-face) $\mathrm{C} 12 \cdots \mathrm{C} 33$ & & 3.271 & \\
\hline $\mathrm{C} 1 \cdots \mathrm{C} 22$ & & 3.279 & \\
\hline $\mathrm{C} 7 \cdots \mathrm{C} 16$ & & 3.395 & \\
\hline $\mathrm{C} 13 \cdots \mathrm{C} 31$ & & 3.349 & \\
\hline $\mathrm{C} 14 \cdots \mathrm{C} 31$ & & 3.384 & \\
\hline centroid $\cdots$ centroid $(\mathrm{N} 7 \mathrm{C} 29-\mathrm{C} 33) \cdots(\mathrm{N} 3 \mathrm{C} 11-\mathrm{C} 15)$ & - & 3.581 & - \\
\hline centroid $\cdots$ centroid $\underset{(\mathbf{N} 2 \mathrm{C} 6-\mathrm{C} 10) \cdots(\mathrm{N} 5 \mathrm{C} 19-\mathrm{C} 23)}{ }$ & - & 3.907 & - \\
\hline $\mathrm{N} 6 \cdots \mathrm{H} 4-\mathrm{C} 4(\mathrm{x}+1 / 2,-\mathrm{y}+1 / 2, \mathrm{z}+1 / 2)$ & 2.556 & $3.484(8)$ & 177.44 \\
\hline $\mathrm{N} 6 \cdots \mathrm{H} 7-\mathrm{C} 7(\mathrm{x}+1 / 2,-\mathrm{y}+1 / 2, \mathrm{z}+1 / 2)$ & 2.438 & $3.361(8)$ & 176.01 \\
\hline $\mathrm{O} 1 \cdots \mathrm{H} 2-\mathrm{C} 2(\mathrm{x}+1 / 2,-\mathrm{y}+1 / 2, \mathrm{z}+1 / 2)$ & 2.531 & $3.402(8)$ & 156.21 \\
\hline $\mathrm{O} 1 \cdots \mathrm{H} 14-\mathrm{C} 14(\mathrm{x}+1 / 2,-\mathrm{y}+1 / 2, \mathrm{z}+1 / 2)$ & 2.574 & $3.310(8)$ & 136.39 \\
\hline $\mathrm{O} 2 \cdots \mathrm{H} 12-\mathrm{C} 12(\mathrm{x}+1 / 2,-\mathrm{y}+1 / 2, \mathrm{z}+1 / 2)$ & 2.401 & $3.268(8)$ & 155.15 \\
\hline $\mathrm{O} 2 \cdots \mathrm{H} 9-\mathrm{C} 9(\mathrm{x}+1 / 2,-\mathrm{y}+1 / 2, \mathrm{z}+1 / 2)$ & 2.367 & $3.258(8)$ & 160.16 \\
\hline $\mathrm{Cl} 1 \cdots \mathrm{H} 15-\mathrm{C} 15(\mathrm{x}+1 / 2,-\mathrm{y}+1 / 2, \mathrm{z}+1 / 2)$ & 3.107 & $3.919(8)$ & 146.9 \\
\hline centroid $\cdots$ centroid $(\mathrm{N} 2 \mathrm{C} 6-\mathrm{C} 10) \cdots(\mathrm{N} 3 \mathrm{C} 11-\mathrm{C} 15)$ & - & 3.679 & - \\
\hline
\end{tabular}

that even though cadmium acetate has higher antibacterial effects and this combination reduce its activity but the complexes still show significant activity that may in part be associated with the presence of $\mathrm{Cd}$, ligand and specially anions. ${ }^{27,28}$ The molecular mechanism of the antibacterial activity of these complexes may be related to their effects on the bacterial plasma or cytoplasmic membrane which is associated with many important enzymes and as an important target site for these complexes with anions. In addition to their effects on bacterial enzymes, it is possible that these complexes inhibit bacterial growth and cell division and damage the cell envelope and contents of bacteria. ${ }^{27,28} \mathrm{MIC}$ is the lowest concentration of an antimicrobial agent that will inhibit the visible growth of a microorganism after incubation and its amount shows resistance of microorganisms to an antimicrobial agent. Here, the MIC amounts are $6.25-100 \mathrm{mg} / \mathrm{ml}$, that there

Table 4. Antibacterial activities (zone of growth inhibition and minimal inhibitory concentrations) of Cltpy ligand and Cd (II) complexes and gentamicine (as a standard compound).

\begin{tabular}{|c|c|c|c|c|c|c|c|}
\hline \multirow[b]{2}{*}{ Method } & \multirow[b]{2}{*}{$\begin{array}{c}\text { Main } \\
\text { compounds }\end{array}$} & \multicolumn{6}{|c|}{ Microorganisms } \\
\hline & & $\begin{array}{c}\text { Klebsiella } \\
\text { pneumonia }(-)\end{array}$ & $\begin{array}{c}\text { Escherichia } \\
\operatorname{coli}(-)\end{array}$ & $\begin{array}{l}\text { Pseudomonas } \\
\text { aeruginosa }(-)\end{array}$ & $\begin{array}{l}\text { Stereptococcs } \\
\text { pyogenes }(+)\end{array}$ & $\begin{array}{c}\text { Bacillus } \\
\text { anthracis }(+)\end{array}$ & $\begin{array}{l}\text { Staphytococus } \\
\text { aureus }(+)\end{array}$ \\
\hline \multirow{4}{*}{$\begin{array}{l}\text { Growth Inhibitory } \\
\text { zone }[\mathrm{mm}]\end{array}$} & Cltpy & 10 & 15 & 20 & 30 & 25 & 15 \\
\hline & (1) & 35 & 20 & - & - & 30 & 30 \\
\hline & (2) & 25 & 25 & 30 & 20 & 25 & 25 \\
\hline & $\mathrm{Cd}(\mathrm{OAC})_{2}$ & 45 & 40 & 35 & 40 & 40 & - \\
\hline Standard & Gentamicine & 20 & 25 & 15 & 13 & 32 & 20 \\
\hline \multirow{4}{*}{$\begin{array}{l}\text { Minimum inhibitory } \\
\text { concentration } \\
(\mathrm{mg} / \mathrm{ml})(\mathrm{MIC})\end{array}$} & $\mathrm{L}$ & 100 & 100 & 50 & 6.25 & 12.5 & 100 \\
\hline & (1) & 6.25 & 50 & - & - & 6.25 & 6.25 \\
\hline & (2) & 12.5 & 12.5 & 6.25 & 50 & 12.5 & 12.5 \\
\hline & $\mathrm{Cd}(\mathrm{OAC})_{2}$ & 3.12 & 3.12 & 6.25 & 3.12 & 3.12 & - \\
\hline
\end{tabular}


are not so high. Growth inhibition zone and MIC have reverse relation: when the growth inhibition zone is increased, the value of MIC is decreased (table 3).

\section{Conclusion}

We have successfully designed and synthesized cadmium-Cltpy complexes, $\left[\mathrm{Cd}(\mathrm{Cltpy})\left(\mathrm{N}_{3}\right)\right.$ $\left.\left(\mathrm{CH}_{3} \mathrm{COO}\right)\right]$, 1, and $\left[\mathrm{Cd}(\mathrm{Cltpy})(\mathrm{NCS})\left(\mathrm{CH}_{3} \mathrm{COO}\right)\right]_{\mathrm{n}}$, 2, with different structures by diffusion along a thermal gradient in methanol solution (the branched tube method). By changing linkers (from $\mathrm{N}_{3}$ to $\mathrm{SCN}$ ) the compounds have been developed from discrete complexes to 1D polymeric chain. These results proved that it was an effective way to synthesize different cadmium compounds of Cltpy. The obtained data also proved that the longer or flexible linker will be in favour of the formation of coordination polymers. The single crystal $\mathrm{X}$-ray analyses show that the coordination number in these complexes is seven with three terpyridine (Cltpy) $\mathrm{N}$-donor atoms, two acetate oxygens and two anionic bridged ligands. The antibacterial activities of Cltpy and its $\mathrm{Cd}$ (II) complexes are tested against different bacteria. The free ligand has considerable activity against Staphylococcus aureus, Bacillus anthracis and Pseudomonas aeruginosa (inhibitory zones $\geq$ $20 \mathrm{~mm}$ ), but has moderate activity against Escherichia coli and Streptococcus pyogenes (inhibitory zones $\leq$ $15 \mathrm{~mm}$ ). It is inactive against Klebsiella pneumonia. Although antibacterial activity of complex $\mathbf{1}$ against Pseudomonas aeruginosa and Escherichia coli is better than complex $\mathbf{2}$, both complexes have shown good activity against all tested bacteria. Against Klebsiella pneumonia and Staphylococcus aureus, antibacterial activities of complexes are higher than Cltpy ligand. The higher activity of complexes was explained on the basis of chelation theory.

\section{Supporting information}

CCDC reference numbers 799985 and 799988 contain the supplementary crystallographic data for this paper. These data can be obtained free of charge at www.ccdc.cam.ac.uk/conts/retrieving.html.

\section{Acknowledgements}

This work was supported by the Payame Noor University in I.R. of Iran and Facultad de Quimica, Universidade de Vigo, 36310 Vigo Pontevedra in Spain.

\section{References}

1. (a) Huang W, You W, Wang L and Yao C 2009 Inorg. Chim. Acta 362 2127; (b) Balzani V and Scandola F 1991 Supramolecular photochemistry (UK: Ellis Harwood Ltd)

2. Balzani V, Juris A, Venturi M, Campagna S and Serroni S 1996 Chem. Rev. 96759

3. Harriman A and Ziessel R 1996 Chem. Commun. 151707

4. Barigelletti F, Flamigni L, Collin J P and Sauvage J P 1997 Chem. Commun. 4333

5. Oshio H, Spiering H, Ksenofontov V, Renz F and Gutlich P 2001 Inorg. Chem. 401143

6. Michalec J F, Bejune S A, Cuttell D G, Summerton G C, Gertenbach J A, Field J S, Haines R J and McMillin D R 2001 Inorg. Chem. 402193

7. Mutai T, Cheon J D, Arita S and Araki K 2001 J. Chem. Soc. Perkin Trans. 71045

8. Armspach D, Constable E C, Diederich F, Housecroft C E and Nierengarten J F 1998 Chem. Eur. J. 4723

9. Hunter CA 1994 Chem. Soc. Rev. 23101

10. Desiraju G R 1997 Chem. Commun. 161475

11. (a) Etter M C 1990 Acc. Chem. Res. 23 120; (b) Huang W, Zhu H B and Gou S H 2006 Coord. Chem. Rev. 250 414; (c) Feng H, Zhou X-P, Wu T, Li D, Yin Y-G and Ng S W 2006 Inorg. Chim. Acta 3594027

12. Zhang C-F, Huang H-X, Liu B, Chen M and Qiana D-J 2008 J. Luminescence 128469

13. (a) Anthonysamy A, Balasubramanian S, Shanmugaiah V and Mathivanan N 2008 Dalton Trans. 2136; (b) MacLachlan M J, Ginzburg M, Coombs N, Coyle T W, Raju N P, Greedan J E, Ozin G A and Manners I 2000 Science 287 1460; (c) Clarke M J, Zhu F and R. Frasca D 1999 Chem. Rev. 992511

14. (a) Cummings S D 2009 Coord. Chem. Rev. 253 1495; (b) Kelland L R 1999 J. Inorg. Biochem. 77 121; (c) Lowe G, Droz A S, Vilaivan T, Weaver G W, Park J J, Pratt J M, Tweedale L and Kelland L R 1999 J. Med. Chem. 423167

15. Lowe G, Droz A S, Vilaivan T, Weaver G W, Tweedale L, Pratt J M, Rock P, Yardley V and Croft S L 1999 J. Med. Chem. 42999

16. Baver A, Kirby W M M, Sherris J E and Turck M 1986 Am. J. Clin. Pathol. 45493

17. (a) Saghatforoush L A, Chalabian F, Aminkhani A, Karimnezhad G and Ershad S 2009 Eur. J. Med. Chem 44 4490; (b) Chew K-B, Tarafder M T H, Crouse K A, Al A M, Yamin B M and Fun H-K 2004 Polyhedron 23 1385

18. Cummings S D 2009 Coord. Chem. Rev. 2531495

19. Jain A, Winkel B S J and Brewer K J 2007 J. Inorg. BioChem. 1011525

20. Sheldrick G M and SHELXL97 1997 Program for the refinement of crystal structures (Germany: University of Gottingen)

21. Farrugia L J 1997 J. Appl. Crystallogr. 30565

22. Mercury 1.4.1, Copyright Cambridge Crystallographic Data Centre, 12 Union Road, Cambridge, CB2 1EZ, UK, 2001-2005

23. Dong Y-B, Layland R C, Smith M D, Pschirer N G, Bunz U H F and zur Loye H-C 1999 Inorg. Chem. 383056

24. Fujita M, Kwon Y J, Sasaki O, Yamaguchi K and Ogura K 1995 J. Am. Chem. Soc. 1177287 
25. Zaman M B, Smith M D and zur Loye H-C 2001 Chem. Mater. 133534

26. (a) Gou L, Zhang B, Hu H M, Chen X L, Wang B C, Wu Q R, Qin T and Tang Z X 2008 J. Mol. Struct. 889 244; (b) Gou L, Wu Q R, Hu H M, Qin T, Xue G L, Yang M L and Tang Z X 2008 Polyhedron 27 1517; (c) Granifo J,
Garland M T and Baggio R 2004 Inorg. Chem. Commun. 7 77; (d) You W, Huang W, Fan Y and Yao C 2009 J. Coord. Chem. 622125

27. Marshall V M E and Reiter B 1980 J. Gen. Microbiol. 120513

28. Chohan Z H and Praveen M 1999 Metal-Based Drugs 695 